\title{
Estimation of Freight Trip Generation Rates based on Commodity Flow Survey in Korea
}

\author{
Minchoul Park, Hongmo Sung* and Sungbong Chung ${ }^{\dagger}$
}

\begin{abstract}
In Korea, almost 700 industrial parks are under operation. Generally, industrial parks consist of national industrial parks and local industrial parks which are managed by a central government and by local governments respectively. The developing countries such as Korea, China and Vietnam etc. have constructed many industrial parks, which result in the change of land use pattern and also affect future trip demands. Therefore, in estimating traffic demands, it is very important to consider the industrial park development. This study aims to improve the methodology in estimating a freight trip generation rate with the data based on a nationwide commodity freight survey. The result showed that it is desirable to apply freight trip generation rate by the industry sector in estimating freight trip generations and using the production area of firm as an indicator. Specially, the reliability of the rates through a survey could be made sure because a sample rate based on firms in industrial parks was over $25 \%$ and the response rate was over $67 \%$. The sample rate and response rate are very superior as compared to surveys conducted in many other countries. Because industrial parks have significant effects on forecasting transportation demand in pre-feasibility studies of transport and logistics projects, it is expected that the accuracy of freight trip demands would be improved through the results of this study.
\end{abstract}

\section{Keywords : Industrial parks, Transportation demand, National-wide commodity freight survey, Freight trip generation rate}

\section{Introduction}

Industrial parks consist of national industrial parks managed by a central government and local industrial parks managed by local governments. Because an industrial park is very huge as a facility, the nationwide development of an industrial park results in the change of land use pattern and also affects on future trip demands. Therefore, in order to estimate traffic demands considering an industrial park development, some countries have provided freight trip generation rates for reliable analysis. The Ministry of Strategy and Finance in Korea conducts the pre-feasibility study for efficient budget allocation. Every year over 10 studies are implemented and freight trip generation rates for industrial parks are also applied to all these studies.

\footnotetext{
$\dagger$ Corresponding author: Professor, Graduate School of Railroad Seoul National University of Science and Technology 138 Gongneung-gil, Nowon-gu, Seoul 139743, Korea

E-mail : sbchung@snut.ac.kr

* The Korea Transport Institute, Korea
}

In Trip Generation Handbook of the United States, it is recommended to use the standard process and values in coming up with trip generation rates. (1) However, it has some problems in forecasting traffic demands and developing an industrial park using these rates. Due to the lack of samples, the trip generation rates in ITE Trip Generation have a low reliability and they are different from the trip generation rates estimated by each state. Recently, to resolve these problems, National Association of Industrial and Office Properties (NAIOP) tried to adjust the discordance between the trip generation rates for land use of warehouse and distribution. (2)

An industrial park, generally, consists of firms that have various sectors of industry. Thus, even if the size and the location of industrial parks are similar to each other, the freight characteristics are very different among them. For this reason, it is known to be difficult to have a standard value of freight trip generation rate for an industrial park. Most transport projects apply freight trip generation rates used in similar projects or obtained through sample survey for the industrial parks in the vicinity of target area. 
However, if the trip generation rates used in different projects are applied without considering the characteristics by the type of industrial park as well as the characteristics of firms in an industrial park such as the sector of industry, the number of employees, the area of facilities and so on, the expected traffic demands would be probably unreliable and uncertain.

This study aims to estimate a freight trip generation rate considering the type of industrial park and the sector of industry of firms, based on the results of a nationwide commodity freight survey. To do this, by analyzing freight trip generations per employee, unit production area and unit total area, a significant variable for explaining freight trip generation rates are drawn. In addition, in order to make sure whether the freight trip generation rate is reasonable, we compared the number of in and out trucks counted with the number of freight trips calculated using the freight trip generation rate.

\section{Literature Review and Problems in Estimating Freight Trip Generation Rates}

In general, freight trip generation rates of industrial parks in Korea have been estimated by three methods. First, the rate is calculated by using traffic volumes counted at facilities. Second, the rate is computed by using freight trip generations of industrial parks which are provided by Korea Industrial Complex Corporation. Finally, the rate is computed by using the traffic volume data obtained from a commodity flow survey as part of national transport database project. Because there has been no confidential method for the estimation of freight trip generation rates in Korea, some projects used the results of a small-scale survey or literature review in forecasting future demand. These methods are, however, inefficient in time and cost, and the results of analysis are likely to be unreliable.

The Institute of Transportation Engineers (ITE) has updated a trip generation manual for many years, which was used widely in traffic engineering and planning. It has two primary purposes; to provide instruction and guidance in the proper use of data presented in Trip Generation and to provide information on supplemental issues in estimating trip generation for development sites. (4) Trip Generation provides, for each land use, guidelines for estimating trip generation and ITE Trip Generation Handbook recommend a procedure for estimating trip generations, which includes the methods such as data plot, weighted average trip generation rate and regression equation. (1) Some regional reports in U.S, however, make comment that ITE trip generation rates poorly reflect real conditions. A report by NAIOP even said that the use of these rates in ITE Trip Generation is impeding the development of facilities related to truck trip, and that the rates are not proven to be accurate. (5) ITE also knows these limits so that ITE Trip Generation Handbook provides guidance for establishing new local trip generation rate and combining local trip generation data if the Trip Generation database for a particular land use is relatively small(e.g., nine or fewer sites).

Freight trip generation rates by land use categories play an enormous role in the overall design and feasibility of development projects. Although trip generation rates provided by ITE are often used in the United States, the trip generation rate is usually different depending on the characteristics of regional land use pattern and occupied facilities. (6) Also, due to the low reliability of trip generation rates from Trip Generation Handbook, actual freight trip generation rates applied to the projects in individual state are recalculated by an additional investigation. (1) Thus, ITE Trip Generation Handbook provides additional investigation criteria for using the rates from ITE Trip Generation and regional trip generation rates calculated by selfsurvey. (6)

In Korea, there are not standard trip generation rates for various land uses. Until now, there has not been enough investigation and research for standard trip generation rate in spite of the importance of freight trip generation rate. In special, even though huge industrial parks are constructed and operated nationally and many industrial parks are considered in trip demand forecasting in pre-feasibility studies, there has not been fundamental researches for the estimation of freight trip generation rates of industrial parks. Problems in estimation of freight trip generation rates can be as follows.

- Absence of transferability of freight trip generation rates

- Absence of a standard procedure for estimating freight trip generation rates

- Absence of a standard methodology for calculating freight trip generation rates

- Absence of a proper sample size for collecting data

- Absence of standard trip generation rates which can reflect the characteristics of industrial parks

\section{Survery And Analysis}

\subsection{Commodity Flow Survey in Korea}

Commodity flow survey was carried out in 2005, but commodity flow survey aimed to make freight ODs and trips not to make freight trip generation rate for specific facilities. (3) Thus an additional survey needed to be car- 
Table 1. Freight Trip Generation Rates per Employee by the Type of Industrial Park

\begin{tabular}{ccccccc}
\hline \multirow{2}{*}{ Type of industrial park } & \multicolumn{2}{c}{ Inbound } & \multicolumn{3}{c}{ Outbound } \\
\cline { 2 - 8 } & Mean (trips) & Standard Deviation (trips) & CV & Mean (trips) & Standard Deviation (trips) & CV \\
\hline National & 0.11 & 0.34 & 3.2 & 0.11 & 0.55 & 5.1 \\
\hline Local & 0.11 & 0.35 & 3.0 & 0.11 & 0.61 & 5.3 \\
\hline Agro & 0.12 & 0.40 & 3.4 & 0.12 & 0.57 & 4.9 \\
\hline
\end{tabular}

Table 2. Freight Trip Generation Rates per 100 Square Meter of Production Area by the Type of Industrial Park

\begin{tabular}{cccccccc}
\hline \multirow{2}{*}{ Type of industrial park } & \multicolumn{2}{c}{ Inbound } & \multicolumn{3}{c}{ Outbound } \\
\cline { 2 - 8 } & Mean (trips) & Standard Deviation (trips) & CV & Mean (trips) & Standard Deviation (trips) & CV \\
\hline National & 0.5 & 1.2 & 2.3 & 0.5 & 2.0 & 3.8 \\
\hline Local & 0.5 & 1.4 & 2.6 & 0.5 & 1.9 & 3.5 \\
\hline Agro & 0.2 & 0.6 & 2.6 & 0.2 & 0.9 & 3.6 \\
\hline
\end{tabular}

Table 3. Freight Trip Generation Rates per Employee by Sector

\begin{tabular}{ccccccc}
\hline \multirow{2}{*}{ Sectors } & \multicolumn{3}{c}{ Inbound } & \multicolumn{3}{c}{ Outbound } \\
\cline { 2 - 7 } & Mean (trips) & Standard Deviation (trips) & CV & Mean (trips) & Standard Deviation (trips) & CV \\
\hline Food/Beverage & 0.09 & 0.20 & 2.2 & 0.13 & 0.40 & 3.2 \\
\hline Textile/Clothing/Shoes & 0.08 & 0.24 & 3.1 & 0.09 & 0.32 & 3.5 \\
\hline Wood/Paper/Printing & 0.12 & 0.31 & 2.6 & 0.19 & 0.55 & 2.9 \\
\hline Petro-chemical & 0.10 & 0.34 & 3.3 & 0.19 & 0.67 & 3.4 \\
\hline Non-metallic material & 0.14 & 0.45 & 3.1 & 0.28 & 0.24 & 4.5 \\
\hline Primary metal & 0.10 & 0.39 & 3.9 & 0.25 & 0.5 & 2.8 \\
\hline Machinery/Metallic parts & 0.14 & 0.37 & 2.6 & 0.19 & 0.37 & 3.0 \\
\hline Electronics/Electricity & 0.12 & 0.37 & 3.1 & 0.13 & 0.81 & 2.9 \\
\hline Transportation equipment & 0.11 & 0.21 & 2.0 & 0.21 & 0.38 & 3.8 \\
\hline Others & 0.11 & 0.28 & 2.6 & 0.15 & & 2.6 \\
\hline
\end{tabular}

ried out to estimate freight trip generation rates of industrial parks. The survey was consisted of two kind of survey. The first one is an interview survey for a questionnaire working at firm and to get information general and logistic characteristics of firms in industrial parks. The other is to count the number of in- and out- bound freight truck at boundaries of a few industrial parks and to analyze the characteristics of freight truck trip. The number of truck trip can be used to validate freight trip generation rate estimated based on the result of interviews. Firms in industrial parks were classified by 10 sectors of industry based on Korean standard industrial classification.

Samples are selected out of 40,000 firms that have various sectors of industry and the size of production facility in all industrial parks. Therefore, when we design a set of samples, the type of industrial park, the sector of industry and the size of firms should be considered. The initial sample of firms was 5,200, but preliminary contacts for 7,848 firms through phone calls were carried out and
5,277 firms made a response finally. Thus the response rate of interviews was over $67 \%$.

\subsection{Estimation of freight trip generation rate}

As you can see in the Table 1 and 2, they show freight trip generation rates per employee and 100 square meters of production area by the type of industrial park. Inbound and outbound freight trip generation rate are not different, but freight trip generation rate per employee and production area are different. The coefficient of variation $(\mathrm{CV})$ of freight trip generation is larger when employee rather than production area is used as an independent variable. Thus, if we use production area as an independent variable, more strict and stable freight trip generation rates can be obtained.

The data related to freight trip generations per employee and 100 square meter of production area by the sector of industry are shown in the Table 3 and 4. Inbound truck trip generation rate is lower than outbound one and $\mathrm{CV}$ is 


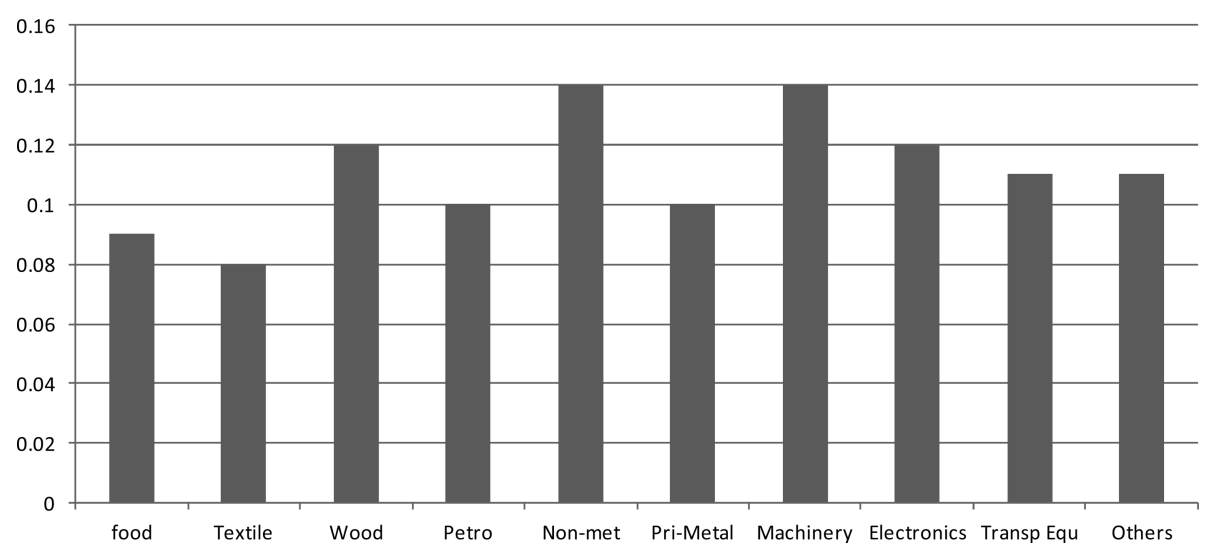

Fig. 1 Freight trip generation rates per employee by sector

Table 4. Freight Trip Generation Rates per 100 Square Meter by Sector

\begin{tabular}{|c|c|c|c|c|c|c|}
\hline \multirow{2}{*}{ Sectors } & \multicolumn{3}{|c|}{ Inbound } & \multicolumn{3}{|c|}{ Outbound } \\
\hline & Mean (trips) & Standard Deviation (trips) & $\mathrm{CV}$ & Mean (trips) & Standard Deviation (trips) & $\mathrm{CV}$ \\
\hline Food/Beverage & 0.45 & 1.07 & 2.4 & 0.57 & 1.83 & 3.2 \\
\hline Textile/Clothing/Shoes & 0.18 & 0.62 & 3.4 & 0.28 & 3.05 & 11.1 \\
\hline Wood/Paper/Printing & 0.30 & 0.81 & 2.7 & 0.65 & 3.80 & 5.8 \\
\hline Petro-chemical & 0.27 & 0.91 & 3.3 & 0.40 & 1.16 & 2.9 \\
\hline Non-metallic material & 0.27 & 0.82 & 3.0 & 0.31 & 0.99 & 3.2 \\
\hline Primary metal & 0.25 & 1.08 & 4.2 & 0.37 & 1.25 & 3.4 \\
\hline Machinery/Metallic parts & 0.43 & 1.17 & 2.7 & 0.53 & 1.58 & 3.0 \\
\hline Electronics/Electricity & 0.62 & 1.52 & 2.5 & 0.74 & 2.06 & 2.8 \\
\hline Transportation equipment & 0.33 & 0.81 & 2.5 & 0.52 & 1.79 & 3.4 \\
\hline Others & 0.33 & 0.74 & 2.3 & 0.39 & 0.92 & 2.4 \\
\hline
\end{tabular}

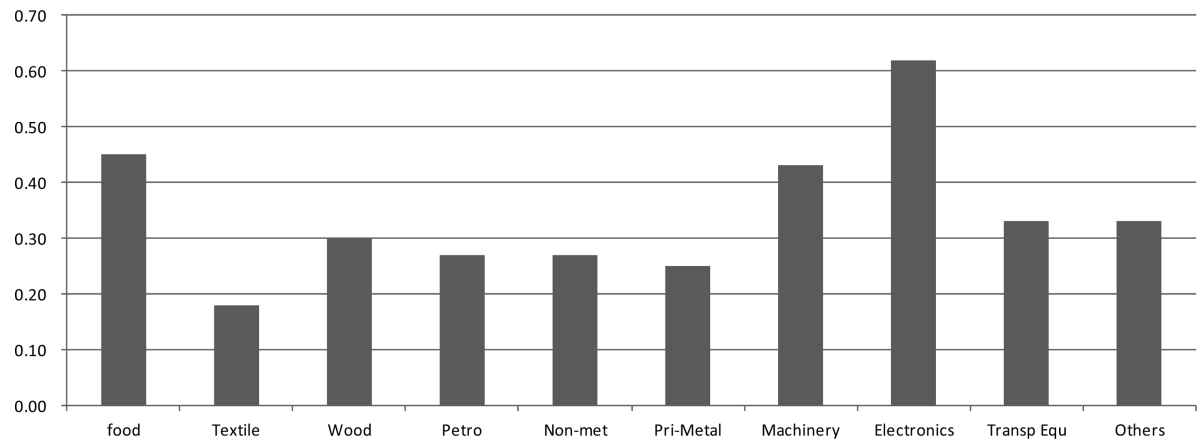

Fig. 2 Freight trip generation rates per 100 square meter by sector

alike. As freight trip generation rates by the type of industrial park are, the rates per employee and unit production area by the sector of industry are very different. To make sure which variable is appropriate to use an independent variable of freight trip generation rates, the validation for freight trip generation rates was carried by comparing the number of truck trips by a counting survey with the number of truck trips computed by freight trip generation rates.

\subsection{Validation of freight trip generation}

In order to make sure whether the estimated freight trip generation rates are reasonable, we compared the number 
Table 5. Total Absolute Differences between the Number of Truck Trips Obtained by a Counting Survey and Computed by Freight Trip Generation Rates

\begin{tabular}{ccccc}
\hline \multirow{2}{*}{$\begin{array}{c}\text { Applied Trip } \\
\text { Rates }\end{array}$} & \multicolumn{2}{c}{$\begin{array}{c}\text { Inbound } \\
\text { (trips) }\end{array}$} & $\begin{array}{c}\text { Outbound } \\
\text { (trips) }\end{array}$ \\
\cline { 2 - 5 } & $\begin{array}{c}\text { Number of } \\
\text { Employee }\end{array}$ & $\begin{array}{c}\text { Production } \\
\text { area }\end{array}$ & $\begin{array}{c}\text { Number of } \\
\text { Employee }\end{array}$ & $\begin{array}{c}\text { Production } \\
\text { area }\end{array}$ \\
\hline $\begin{array}{c}\text { By the type } \\
\text { of industrial } \\
\text { park }\end{array}$ & 76.86 & 47.64 & 76.90 & 47.74 \\
\hline $\begin{array}{c}\text { By the sector } \\
\text { of industry }\end{array}$ & 77.19 & 43.18 & 46.88 & 35.67 \\
\hline
\end{tabular}

of in and out truck trips counted with the number of truck trips computed by the estimated freight trip generation rates to a few industrial parks available to count in and out truck trips. Table 5 represents total absolute differences between the number of truck trips obtained by a counting survey and computed by freight trip generation rates by the type of industrial park and by the sector of industry. Total absolute difference of results using freight trip generation rate by the type of industrial park is lower than that by sector of industry, and when freight trip generation per production area rather than truck trip generation per employee is used, absolute differences are smaller. Thus, this result shows production area is more effective independent variable than employee for estimating freight trip generation rates of industrial parks. Finally, we propose to use freight truck trip generation rates by the sector of industry of which an independent variable is production area, in estimating freight trip generations of industrial parks.

\section{Conclusions}

In this study, freight trip generation rates which can be applied to forecasting traffic demands of transport and logistics projects was estimated. To make sure the stability of the rates, we compared between freight trip generation rates by the type of industrial park and that by the sector of industry indicator. In addition, the results using the production area of firm and the number of employees as an indicator of firm size was analyzed using counting data surveyed on boundaries of a few industrial parks. The result showed that it is desirable to apply freight trip generation rate by the sector of industry to estimate freight trip generations and use the production area of firm as an indi- cator. Specially, the reliability of the rates through a survey could be made sure because a sample rate based on firms in industrial parks was over $25 \%$ and the response rate was over $67 \%$. The sample rate and response rate are very superior as compared surveys conducted in many countries. Due to the results of validation, total absolute difference of results using freight trip generation rate by the type of industrial park is lower than that by sector of industry, and when freight trip generation per production area rather than truck trip generation per employee is used, absolute differences are smaller. Thus, this result shows production area is more effective independent variable than employee for estimating freight trip generation rates of industrial parks. Based on the results analyzed through the survey, We propose to use freight truck trip generation rates by the sector of industry of which an independent variable is production area, in estimating freight trip generations of industrial parks. Because industrial parks have significant effects on reliable demand forecasting in prefeasibility studies of transport and logistics projects, it is expected that the accuracy of freight trip demands would be improved through the results of this study.

\section{Acknowledgement}

This paper was presented at the $3^{\text {rd }}$ conference on Innovation in Travel Modeling 2010 and slightly changed and edited.

\section{References}

1. Institute of Transportation Engineers (ITE), Trip Generation Handbook, ITE, Washington, D.C., 2004.

2. Raymond B., B. Paul, and G.B. William, Truck Trip Generation Study, City of Fontana, 2003.

3. The Korea Transport Institute (KOTI), Commodity Flow Survey in Korea, 2006.

4. Fischer, M.J. and M. Han, NCHRP Synthesis Report 298: Truck Trip Generation Data, Transportation Research Board, National Research Council, Washington, D.C., 2001.

5. Redman D.H., Investigation into ITE Handbook Truck Trip Generation Rates for Warehouse/ Distribution Land Uses Project Report, National Association of Industrial and Office Properties, 2003.

6. Institute of Transportation Engineers (ITE), Trip Generation, 8th ed., ITE, Washington, D.C., 2008.

Received(October 8, 2012), Revised(October 25, 2012),

Accepted(November 20, 2012) 